\title{
Generation of primordial germ cells from pluripotent stem cells
}

\author{
Cristina Eguizabal ${ }^{\star}$, Tanya C. Shovlin ${ }^{\star}$, Gabriela Durcova-Hills, Azim Surani, and Anne \\ McLaren ${ }^{\dagger}$ \\ Wellcome Trust/Cancer Research UK Gurdon Institute, Henry Wellcome Building of Cancer and \\ Developmental Biology, University of Cambridge, Tennis Court Road, Cambridge, CB2 1QN, UK
}

\begin{abstract}
Embryonic stem (ES) cells, derived from pre-implantation embryo and embryonic germ (EG) cells, derived from embryonic precursors of gametes, primordial germ cells (PGCs), can differentiate into any cell type in the body. Moreover, ES cells have a capacity to differentiate into PGCs in vitro. In the present study we have shown the differentiation capacity of six EG cell lines to form PGCs in vitro, in comparison to ES cells. Cell lines were differentiated via embryoid body (EB) formation using the co-expression of mouse vasa homologue (Mvh) and Oct-4 to identify newly formed PGCs in vitro. We found an increase of PGC numbers in almost all analysed cell lines in 5 days old EBs thus suggesting that EG and ES cells have similar efficiency to generate PGCs. The addition of retinoic acid confirmed that the cultures had attained a PGC like identity and continued to proliferate. Furthermore we have shown that the expression pattern of Prmt5 and $\mathrm{H} 3 \mathrm{~K} 27 \mathrm{me} 3$ in newly formed PGCs is similar to that observed at embryonic day E11.5 PGCs in vivo. By co-culturing EBs with $\mathrm{CHO}$ cells some of the PGCs entered into meiosis, as judged by Scp3 expression. The derivation of germ cells from pluripotent stem cells in vitro could provide an invaluable model system to study both the genetic and epigenetic programming of germ cell development in vivo.
\end{abstract}

\section{Keywords}

Pluripotent stem cell; EG cells; ES cell; Differentiation; Embryoid bodies; PGCs

\section{Introduction}

The germ line provides the continuity of life between generations. All sexually reproducing organisms arise from the gametes - sperm and eggs - and the primordial germ cells (PGCs) are the founder cells of these gametes. The PGCs are a highly specified cell lineage, derived from a subset of cells in the epiblast, and undergo major reprogramming events during their development (Ohinata et al., 2005; Ueno et al., 2009).

In the mouse PGCs are specified at embryonic day E7.25 when about forty PGCs are localised at the base of allantois, where they express Dpp3 (Stella or PGC7) and Akp2 (tissue non-specific alkaline phosphatase, TNAP) genes. Several studies have demonstrated that bone morphogenetic protein 4 and 2 (BMP-2 and BMP-4), both secreted from the extraembryonic ectoderm, are required for this PGCs specification (Lawson et al., 1999,

\footnotetext{
Correspondence to: Cristina Eguizabal.

†We dedicate this manuscript to Anne McLaren who tragically died on $7^{\text {th }}$ July 2007.

*Present address: CE: Center of Regenerative Medicine in Barcelona, Dr. Aiguader 88, 08003 Barcelona, Spain. TCS: Regional Histocompatibility and Immunogenetics Lab., Blood Transfusion Service Building, Belfast City Hospital, Lisburn Road, Belfast BT9 7TS, Ireland.
} 
Ying and Zhao et al., 2001, Ying et al., 2001). Recently a critical role for Prdml (Blimp1) and Prdm 14 in the formation of PGC precursors E6.25-7.25 was demonstrated. In PGCs, Blimp1 forms a complex with Prmt5, histone methyltransferase, and suggesting a role in PGC development (Ancelin et al., 2006). Once PGCs are specified they migrate towards to genital ridges, the future gonads, and start to express germ-cell-specific genes such as mouse vasa homolog $(M v h)$, germ cell nuclear factor (Gcna-1). At E11.5 to 12.5 PGCs have undergone epigenetic reprogramming including the genome-wide demethylation, erasure of parental imprints, histone modifications and activation of $\mathrm{X}$ chromosome in female embryos (Hajkova et al., 2002; 2008; Chuva de Sousa Lopes et al., 2008). At E12.5 PGCs enter mitotic arrest in male and enter prophase of meiosis I in female.

In the pre-implantation embryo, the inner cell mass (ICM)/early epiblast of blastocyst can give rise to ES cells (Evans et al., 1981; Martin et al., 1981). In the post-implantation embryo, at embryonic days (E) 8.0 to 12.5, mono-potent primordial germ cells (PGCs) can give rise to EG cells when exposed to appropriate culture conditions (Matsui et al., 1992; Resnick et al., 1992). Both pluripotent stem cells, embryonic stem (ES) and embryonic germ (EG) cells, possess the capacity to generate cells of all embryonic lineages when introduced into blastocysts including germ cell lineage.

Since the number of PGCs is limited, particularly in the early stages of development when only few hundred of cells are present in the embryo, EG cells had provided a hope that they may have reflected the biological and epigenetic status of cells from which they were originally derived. However, these initial hopes in EG cells were proved to be ill-founded. PGCs, in contrast to EG cells, do not make chimeras when they are re-introduced into blastocysts (Durcova-Hills et al., 2001, 2006). PGCs also differ from EG cells in expression of several genes associated with pluripotency (Durcova-Hills et al., 2008). Moreover EG cells do not reflect the methylation status of imprinted genes of that in the PGCs from which they were derived (Tada et al., 1998; Durcova-Hills et al., 2001; Hajkova et al., 2002; Shovlin et al., 2008).

Since EG cells are not an appropriate source of cells to study the biology of PGCs there has been a great interest to use new sources or techniques in order to derive PGCs in vitro. Recent successful studies have demonstrated that germ cells can be derived from ES cells in vitro, which further differentiated into oocyte-like cells or spermatogenic-like cells (Hübner et al., 2003; Qing et al., 2007; Toyooka et al., 2003; Geijsen et al., 2004; Nagano et al., 2007; Wei et al., 2008). The differentiation potential of EG cells have been shown in vitro (Beddington et al., 1989; Rohwedel et al., 1996), however there is no available information on EG cells capacity to form germ cells in vitro.

In this study, we have investigated the formation of in vitro PGCs from EG cells in comparison to ES cells. We found that the efficiency of PGCs formation is similar between EG cells and ES cells. We also showed that PGCs formed from differentiating EBs are similar to PGCs colonising the genital ridges in vivo. We believe that this research may provide a new model to study in detail the molecular and epigenetic changes that accompany PGCs formation in vitro and that this model may be a useful tool in the study PGCs specification and their differentiation in other species, including human.

\section{Material and Methods}

\section{Cell lines and their culture}

The following cell lines were used in this study: 8.5 EG cells lines - EGC-1, EGC-2 and EGC8. 11.5 EG cell lines - 4.3 Rosa, TMAS 23G, TMAS 19G. ES cell lines - ESOct4GFP, Kes-1, Kes-5. Almost all EG cells and ES cells were derived in our laboratory as 
previously described (Tada et al., 1998, 2001; Durcova-Hills and McLaren, 2006). ESOct4GFP cells were kindly provided by Prof. Austin Smith. With the exception of ESOct4GFP cell line, cells were cultured on mitomycin-C treated mouse embryonic fibroblast (MEF) cells in DMEM (Invitrogen) containing 15\% fetal calf serum (FCS, tested), sodium pyruvate (Sigma), non-essential amino acids (Invitrogen), penicillin/streptomycin (Invitrogen), $\beta$-mercaptoethanol and $1000 \mathrm{Uml}-1$ Leukaemia inhibitory factor (LIF, Chemicon). ES-Oct4GFP cells were cultured feeder free on pre-gelatinised tissue culture dishes. Bone morphogenenic protein 4 (BMP4) was added to the cultures at a concentration of $25 \mathrm{ng} \mathrm{ml}-1$ to induce PGCs formation from pluripotent stem cells. We used only early passages (under 30) to avoid aberrant changes in cells potentially arising from later passages.

\section{Differentiation in vitro}

For embryoid body (EB) differentiation (Robertson 1987), both EG or ES cells were dissociated with $0.25 \%$ of trypsin-EDTA (Invitrogen) and collected in EB medium (EG/ES medium without LIF). Dissociated cells were plated in hanging drops at concentration of 500 or 800 cells per $20 \mu l$ in Petri dishes (bacteriological, Sterilin). After 3 days, EBs were flushed from lids and cultured in suspension in dishes (bacteriological, Sterilin). EBs were collected after 3 to 9 days of differentiation.

For differentiation of ES/EG cells induced by all-trans retinoic acid (RA, Sigma), collected EBs were digested by collagenase IV treatment $(0.01 \%)$ in order to obtain cell suspensions which were seeded onto mitotically inactive MEF in EB medium supplemented with $2 \mu \mathrm{M}$ RA for 5 days.

\section{Long-term cultures}

Chinese hamster ovary (CHO) cells at $80 \%$ confluence were treated with Mitomycin C in order to make feeders. 5 days old EBs made from EG or ES cells were co-cultured with mitotically inactive $\mathrm{CHO}$ cells for 5, 10 or 12 days. To identify cells in meiosis, samples were immunostaining for detection of SCP-3, a meiosis marker kindly provided by Dr. Hayashi.

\section{Characterisation of the PGC like cells}

EBs were fixed in $4 \%$ paraformaldehyde for 2 hours at room temperature, followed by three washes in PBS and incubation in sucrose solution overnight. Then samples were mounted in OCT media and frozen at $-80^{\circ}$. Serial cryosections of EBs were collected and were permeabilized and blocked in $0.1 \%$ Triton-X/10\% BSA in PBS for $30 \mathrm{~min}$ at room temperature. Primary antibodies diluted in blocking solution were incubated with the samples overnight at $4{ }^{\circ} \mathrm{C}$. Then samples were rinsed with PBS and incubated with the appropriate fluorescently labelled secondary antibodies (Alexa) for 1 hour and $30 \mathrm{~min}$ at room temperature. Rinsed samples were stained with DAPI for $15 \mathrm{~min}$ at room temperature in the dark and mounted with Vectashield medium. Samples were analysed by using confocal laser microscope Biorad Radiance 2100 (Nikon Eclipse E800). Quantitative analysis was performed by counting the total number of Mvh/Oct- 4 positive cells in one EB. The following primary antibodies used in this study: mouse monoclonal Oct3/4 (1:100, BD Biosciences), goat polyclonal Sox-2 (1:50, Santa Cruz), rabbit polyclonal c-myc (1:50, Santa Cruz), rabbit polyclonal DDX4/MVH (1:200, Abcam), rabbit polyclonal PRMT5 (1:250, Millipore), goat polyclonal PRMT5 (1:50, Santa Cruz), mouse monoclonal SSEA-1 (1:1, kindly provided by Dr. Beverly), mouse monoclonal phospho-H3 (ser10) (1:500, Millipore), mouse monoclonal H3-K27 tri-methyl (1:50, Abcam). TNAP staining was also combined with the immunoflourescence staining using the Alkaline Phosphatase Leukocyte kit (Sigma) according to the maufacturer's instructions. Apoptotic cells were detected using 
TUNEL (In situ Cell Death Detection Kit-TMR red, Roche) according to the manufactureŕs instructions and in combination with an immunofluorescence staining.

\section{Results \\ Differentiation potential among cell lines}

In this study we used six EG and three ES cell lines derived in our laboratory except of ESOct4GFP line (Table 1). All cell lines exhibited properties of pluripotent stem cells. They formed compact colonies and cells within colonies expressed Oct-4, Sox-2, c-myc, Prmt5, SSEA-1 and showed high levels of TNAP activity (Fig. 1). All lines were negative for mouse vasa homolog (Mvh) protein, the germ cell marker expressed in $11.5 \mathrm{dpc}$ PGCs onwards (Fig. 1).

Next we examined the differentiation potential of cell lines by their ability to form embryoid bodies (EBs) in vitro. Pluripotent stem cells differentiate into three-dimensional structures called embryoid bodies (EBs) thus mimicking post-implantation embryonic tissues. We examined EBs made from 800 cells after 5 days of culture. Table 2 summarises the results. We found that some cell lines made EBs of round shaped with monolayer of endoderm cells at the edges whereas other cell lines, TMAS 23G, 4-3 Rosa, EGC-2 and Kes-5, formed small, irregular shaped EBs surrounded by many single or small clumps of floating cells. We noticed that small EBs did not form a monolayer of endoderm cells as seen in roundshaped EBs (data not shown) thus suggesting that differentiation potential of four lines is reduced and presumably also their ability to form PGCs in vitro.

\section{Generation of Mvh/Oct-4-positive cells depends on both cell line and culture}

It has been previously shown that ES cells can differentiate into PGCs in vitro (Hübner et al., 2003; Toyooka et al., 2003; Geijsen et al., 2004; Qing et al., 2007; Wei et al., 2008). We differentiated cell lines via EBs formation (West et al., 2006) and adding of Bmp4 into culture media (Toyooka et al., 2003; Wei et al., 2009). Co-expression of Mvh and Oct-4 proteins was used as markers to identify newly formed PGCs in EBs and to distinguish them from un-differentiated (only Mvh-negative/Oct4-positive cells) and differentiated cells but not PGCs (Mvh-negative/Oct-4-negative). EBs made from EG or ES cells were cultured in the presence of BMP4 for 5 days, cryo-sectioned and the PGC numbers were counted. As a control, some EBs were cultured in media without BMP4. The PGC numbers in BMP4 treated EBs and in controls were similar (data not shown) and therefore we decided not to use BMP4 in our further experiments. Next we examined whether a cell number used to make an EB can affect the efficiency of the PGCs formation in vitro when we tested EBs consisting of either 500 or 800 cells for 5 days. We found that EBs made from 800 cells generated more Mvh/Oct4-positive cells that EBs made from 500 cells (data not shown).

Therefore our following experiments were performed on EBs made from 800 cells and differentiated for 3, 4, 5, 6 and 9 days. Serial cryosections made from differentiated EBs were immunostained and examined by confocal microscopy. Only cells co-expressing both Mvh and Oct4 were counted (Fig. 2B). As expected, all cell lines generated Mvh/Oct4positive cells (Figure 3 ). We found that the Mvh/Oct4 positive cell numbers increased up to 5/6 days of EB differentiation and then the numbers decresed. (Fig. 3). In contrast ES Oct4GFP cell line was the most efficient to generate PGCs and moreover the numbers did not decreased in 6/9 old EBs.

Observed changes in the numbers of Oct4/Mvh-positive cells in differentiating EBs might be caused by either cell proliferation or cell death in the course of EB differentiation. To distinguish between these two possibilities, we assessed the EB samples for the presence of 
apoptotic cells by using the tunnel reaction. None of PGCs was positive (Fig. 3B). Next we examined the proliferation rate of in vitro formed PGCs by immunostaining for phosphorylated Histone $\mathrm{H} 3$ ser10, a marker of M phase. The immunostaining analysis on EBs differentiated from 3 to 9 days revealed that many PGCs proliferated suggesting that cells were proliferating in the course of EB differentiation (Fig. 3B).

\section{Mvh/Oct-4 positive cells are PGCs}

We used expression of $M v h$ and $O c t-4$ genes to identify newly formed PGCs in differentiated EBs. To demonstrate that these cells are true in vitro formed PGCs and they are not undifferentiated pluripotent stem cells, we treated our cultures with all-trans retinoic acid (RA). RA induces both differentiation of pluripotent stem cells or proliferation of cultured PGCs (Koshimizu et al., 1995).

Five days old EBs were dissociated into cell suspensions which were subsequently cocultured with mitotically inactive feeder cells in the presence of RA. After 5 days expression of Mvh and TNAP was examined (Fig. 4). As we expected, we observed small colonies of cells positive for both Mvh and TNAP thus confirming that Mvh/Oct-4 positive cells in EBs are true PGCs.

\section{In vitro formed PGCs resemble to E11.5 PGCs in vivo}

PGCs during their development undergo profound epigenetic changes (Hajkova et al., 2008). Our previous results based on the expression of $M v h$ suggested that newly formed PGCs in differentiated EBs are PGCs colonising the genital ridges in vivo. We decided to examine the epigenetic status of in vitro PGCs by analysing the expression of histone methyltransferase Prmt5 and $H 3 \mathrm{~K} 27 \mathrm{me} 3$, repressive marks of histone residues.

We examined expression of Prmt5 and H3K27me3 in 5 days old EBs and found Prmt5 colocalised in the cytoplasm of PGCs with Mvh protein (Fig. 5). Staining of EBs with H3K27me3 antibody revealed the nuclear localisation of H3K27 in Mvh positive cells. Taken together these results suggest that newly formed PGCs are similar to in vivo colonising PGCs at $11.5 \mathrm{dpc}$ stage.

\section{EB-derived PGCs entered into meiosis upon prolonged culture}

We tested whether PGCs derived from EG or ES cells using our culture conditions can generate oocyte-like cells as previously reported using ES cells (Geijsen et al., 2004; Qing et al., 2007). We co-cultured 5 days old EBs made from EG (EGC-1) or ES cells (Kes-1) with $\mathrm{CHO}$ feeders for 5, 10 and 12 days and analyzed the cultures for expression of $S c p 3$, a meiotic marker, by immunofluorescence. In 5 days old EBs we observed co-expression of $S c p 3$ and $M v h$ in approximately 10 cells per EB made from EG cells and 15 cells per EB made from ES cells. In 10 and 12 days old bodies we observed only few Scp3 and Mvh positive cells.

\section{Discussion}

In previous studies it had been showed that mouse ES cells could be differentiated, via EBs formation, to generate germ cells (Toyooka et al., Geijsen et al., 2004; Wei et al., 2008). In this study we confirmed and extended previous observations on the capacity of pluripotent stem cells to generate germ cells in vitro. We showed that both EG and ES cells gave rise to PGCs in vitro, which resembled that of E11.5 PGCs in vivo. Moreover we also observed that both EG and ES cells, despite their different origins, are similar in their efficiency to generate PGCs in vitro, and to further differentiate into Scp3-expressing cells. 
To extend previous works we decided to investigate EG cells along with ES cells to give rise to germ cells in vitro. Since EG cells are derived from PGCs isolated from E8.5 to 12.5 embryos we tested the idea that these cells might be more efficient than ES cells derived from blastocysts. We studied six EG cell lines and three ES cell lines (Table1). Before employing the experiments we characterised all cell lines (Table 2) and found that all lines expressed pluripotency genes but they did not express Mvh-protein, which is a marker of germ cells. However when we examined a differentiation capacity of all lines through EB formation we found that the differentiation potential of a few lines were compromised. Some cell lines formed smaller and more fragile EBs, which exhibited incomplete outer layer of endoderm-like cells, when compared to other EBs which showed the expected morphology after 5 days of culture (Fig. 2B). This could suggest that there is a certain level of heterogeneity among studied lines in their differentiation potential.

We adopted a differentiation protocol similar to protocols published previously (West et al., 2006) with minor modifications. EG or ES cells were aggregated into EBs at 800 cells per body and germ cell identification in EB cultures was determined by co-expression of Mvh and Oct-4 proteins. We, and others used $M v h$ is a reliable identification marker of PGCs and a germ-cell specific ATP-dependent RNA helicase not expressed in pluripotent stem cells (Toyooka et al., 2000) thus enabling to detect germ cells in differentiating EB cultures. We also attempted to increase the formation of PGCs in vitro by adding BMP-4 to EB cultures. BMP-4 has an important role in the process of germ cell specification from pluripotent epiblast cells (Lawson et al., 1999, Ying and Zhao, 2001; Ying et al., 2001). However when we added BMP-4 to cultures we did not observe a significant increase of Mvh/Oct4-positive cells in BMP-4-treated cultures than in control cultures (data not shown). This observation is not in agreement with previous studies in which it has been shown that BMP-4 significantly increased formation of germ cells (Toyooka et al., 2003, Geijsen et al., 2004; Wei et al., 2008). Moreover we found that the cultures without adding BMP-4 generated similar numbers of Mvh/Oct 4 positive cells ( $0.5 \%$ per body) in 5 days old EBs than numbers reported previously using ES cells (Toyooka et al., 2003). Our results thus suggested that both culture conditions and responsiveness of cell lines to BMP-4 may influences the process of PGCs generation in vitro.

We further characterised the in vitro formed PGCs in order to determine which embryonic stage of PGCs development they may correspond to. We observed that Mvh/Oct-4 positive cells expressed the phosphorylated Histone $\mathrm{H} 3$ ser10, a marker of M phase of cell cycle, thus suggesting that the cells proliferate and by applying Tunnel assay we showed that the cells were not dying through apoptosis. Moreover the expression pattern of Mvh, Prmt5 and H3K27 proteins suggested that in vitro formed PGCs in our cultures resembled to colonising E11.5 PGCs in vivo. Further work needs to be address to support our observation that PGCs are resemble to E11.5 PGCs in vivo by assessing their epigenetic status including a methylation status of imprinted genes. It has been established that RA stimulates the PGCs proliferation but induces EG or ES cells differentiation. To prove their PGCs status we treated cultures with retinoic acid when in vitro formed PGCs formed TNAP-positive colonies.

In summary, we have demonstrated an approach for inducing mouse EG cells to differentiate into late PGCs and more differentiated cells, like meiotic oocyte-like cells using a co-culturing system with granulosa cells. Generation of germ cells from EG or ES cells also give a model to address biological questions of germ cell formation but also questions of niche formation. The findings suggest that a niche develops from EG/ES cells during EB differentiation or that PGCs generated in vitro do not require the same somatic support as they do in vivo. Pluripotent stem cells are a unique source of cells to generate PGCs in vitro since the number of PGCs is very limited, particularly in the early stages of PGCs 
development at embryonic day E7.2 -12.5. This approach may also provide a unique model to examine regulation of programming in course of germ cell lineage development in other species including humans. Such an approach could advance our understanding of human germ cell lineage specification and their early development and also provide a source of in vitro form oocytes that are difficult to obtain.

\section{References}

Ancelin K, Lange UC, Hajkova P, Schneider R, Bannister AJ, Kouzarides T, Surani MA. Blimp1 associates with Prmt5 and directs histone arginine methylation in mouse germ cells. Nat Cell Biol. 2006; 8:623-630. [PubMed: 16699504]

Beddington RS, Robertson EJ. An assessment off the developmental potential of embryonic stem cells in the midgestation mouse embryos. Development. 1989; 105:733-737. [PubMed: 2598811]

Chuva de Sousa Lopes SM, Hayashi K, Shovlin TC, Mifsud W, Surani MA, McLaren A. X Chromosome activity in Mouse XX primordial germ cells. PLoS Genetics. 2008; 4(2):30-37.

De Felici M, Scaldaferri ML, Lobascio M, Iona S, Nazzicone V, Klinger FG, Farini D. Experimental approaches to the study of primordial germ cell lineage and proliferation. Hum Reprod Update. 2004; 10(3):197-206. [PubMed: 15140867]

Donovan PJ, De Miguel MP. Turning germ cells into stem cells. Curr Opin Genet Dev. 2003; 13(5): 463-471. [PubMed: 14550410]

Durcova-Hills G, Ainscough J, McLaren A. Pluripotential stem cells derived from migrating primordial germ cells. Differentiation. 2001; 68(4-5):220-226. [PubMed: 11776474]

Durcova-Hills G, Wianny F, Merriman J, Zernicka-Goetz M, Mclaren A. Developmental fate of embryonic germ cells (EGCs), in vivo and in vitro. Differentiation. 2003; 71(2):135-141. [PubMed: 12641567]

Durcova-Hills G, Adams IR, Barton SC, Surani MA, McLaren A. The role of exogenous fibroblast growth factor-2 on the reprogramming of primordial germ cells into pluripotent stem cells. Stem Cells. 2006; 24(6):1441-1449. [PubMed: 16769760]

Durcova-Hills G, Tang F, Doody G, Tooze R, Surani MA. Reprogramming primordial germ cells into pluripotent stem cells. PLoS ONE. 2008; 3(10):e3531. [PubMed: 18953407]

Evans MJ, Kaufman MH. Establishment in culture of pluripotential cells from mouse embryos. Nature. 1981; 292(5819):154-156. [PubMed: 7242681]

Geijsen N, Horoschak M, Kim K, Gribnau J, Eggan K, Daley GQ. Derivation of embryonic germ cells and male gametes from embryonic stem cells. Nature. 2004; 427(6970):148-154. [PubMed: 14668819]

Ginsburg M, Snow MHL, McLaren A. Primordial germ cells in the mouse embryo during gastrulation. Development. 1990; 110:521-528. [PubMed: 2133553]

Hadjantonakis A, Papaioannou V. The stem cells of early embryos. Differentiation. 2001; 68(4-5): 159-166. [PubMed: 11776468]

Hajkova P, Ancelin K, Waldmann T, Lacoste N, Lange UC, Cesari F, Lee C, Almouzni G, Schneider $\mathrm{R}$, Surani MA. Chromatin dynamics during epigenetic reprogramming in the mouse germ line. Nature. 2008; 452(7189):877-881. [PubMed: 18354397]

Hajkova P, Erhardt S, Lane N, Haaf T, EL-Maarri O, Reik W, Walter J, Surani MA. Epigenetic reprogramming in mouse primordial germ cells. Mech Dev. 2002; 117(1-2):15-23. [PubMed: 12204247]

Hayashi K, de Sousa Lopes S, Surani MA. Germ cell specification in mice. Science. 2007; 20:394396. [PubMed: 17446386]

Hayashi K, Kobayashi T, Umino T, Goitsuka R, Matsui Y, Kitamura D. SMAD1 signaling is critical for initial commitment of germ cell lineage from mouse epiblast. Mech Dev. 2002; 118(1-2):99_ 109. [PubMed: 12351174]

Hübner K, Fuhrmann G, Christenson LK, Kehler J, Reinbold R, De La Fuente R, Wood J, Strauss JF, Boiani M, Schöler HR. Derivation of oocytes from mouse embryonic stem cells. Science. 2003; 300(5623):1251-1256. [PubMed: 12730498] 
Koshimizu U, Watanabe M, Nakatsuji N. Retinoic acid is a potent growth activator of mouse primordial germ cells in vitro. Dev Biol. 1995; 168(2):683-685. [PubMed: 7729599]

Kramer J, Hegert C, Hargus G, Rohwedel J. Mouse ES cell lines show a variable degree of chondrogenic differentiation in vitro. Cell biology international. 2005; 29(2):139-146. [PubMed: 15774311]

Labosky PA, Barlow DP, Hogan BL. Mouse embryonic germ (EG) cell lines: transmission through the germline and differences in the methylation imprint of insulin-like growth factor 2 receptor (Igf2r) gene compared with embryonic stem (ES) cell lines. Development. 1994; 120(11):3197-3204. [PubMed: 7720562]

Lacham-Kaplan O. In vivo and in vitro differentiation of male germ cells in the mouse. Reproduction. 2004; 128(2):147-152. [PubMed: 15280553]

Lawson KA, Hage WJ. Clonal analysis of the origin of primordial germ cells in the mouse. Ciba Found Symp. 1994; 182:68-91. [PubMed: 7835158]

Lawson KA, Dunn NR, Roelen BA, Zeinstra LM, Davis AM, Wright CV, Korving JP, Hogan BL. Bmp4 is required for the generation of primordial germ cells in the mouse embryo. Genes Dev. 1999; 13(4):424-436. [PubMed: 10049358]

Lee J, Inoue K, Ono R, Ogonuki N, Kohda T, Kaneko-Ishino T, Ogura A, Ishino F. Erasing genomic imprinting memory in mouse clone embryos produced from day 11.5 primordial germ cells. Development. 2002; 129(8):1807-1817. [PubMed: 11934847]

Loebel DA, Watson CM, De Young RA, Tam PP. Lineage choice and differentiation in mouse embryos and embryonic stem cells. Dev Biol. 2003; 264(1):1-14. [PubMed: 14623228]

Martin GR. Isolation of a pluripotent cell line from early mouse embryos cultured in medium conditioned by teratocarcinoma stem cells. PNAS. 1981; 78(12):7634-7638. [PubMed: 6950406]

Matsui Y, Zsebo K, Hogan BL. Derivation of pluripotential embryonic stem cells from murine primordial germ cells in culture. Cell. 1992; 70(5):841-847. [PubMed: 1381289]

McLaren A. Primordial germ cells in the mouse. Dev Biol. 2003; 262(1):1-15. [PubMed: 14512014]

McLaren A, Durcova-Hills G. Germ cells and pluripotent stem cells in the mouse. Reprod Fertil Dev. 2001; 13(7-8):661-664. [PubMed: 11999318]

Monk M, Boubelik M, Lehnert S. Temporal and regional changes in DNA methylation in the embryonic, extraembryonic and germ cell lineages during mouse embryo development. Development. 1987; 99(3):371-382. [PubMed: 3653008]

Nagano MC. In vitro gamete derivation from pluripotent stem cells: progress and perspective. Biol Reprod. 2007; 76(4):546-551. [PubMed: 17215488]

Nayernia K, Lee JH, Drusenheimer N, Nolte J, Wulf G, Dressel R, Gromoll J, Engel W. Derivation of male germ cells from bone marrow stem cells. Lab Invest. 2006; 86(7):654-663. [PubMed: 16652109]

Nayernia K, Li M, Jaroszynski L, Khusainov R, Wulf G, Schwandt I, Korabiowska M, Michelmann HW, Meinhardt A, Engel W. Stem cell based therapeutical approach of male infertility by teratocarcinoma derived germ cells. Hum Mol Gen. 2004; 13(14):1451-1460. [PubMed: $15163638]$

Nayernia K, Nolte J, Michelmann HW, Lee JH, Rathsack K, Drusenheimer N, Dev A, Wulf G, Ehrmann IE, Elliott DJ, Okpanyi V, Zechner U, Haaf T, Meinhardt A, Engel W. In vitrodifferentiated embryonic stem cells give rise to male gametes that can generate offspring mice. Dev Cell. 2006; 11(1):125-132. [PubMed: 16824959]

Ohinata Y, Payer B, ÓCarrol D, Ancelin K, Ono Y, Sano M, Barton SC, Obukhanych T, Nussenzweig M, Tarakhovsky A, Saitou M, Surani MA. Blimp1 is a critical determinant of the germ cell lineage in mice. Nature. 2005; 436:207-213. [PubMed: 15937476]

Pesce M, Klinger FG, De Felici M. Derivation in culture of primordial germ cells from cells of the mouse epiblast: phenotypic induction and growth control by Bmp4 signalling. Mech Dev. 2002; 112(1-2):15-24. [PubMed: 11850175]

Qing T, Shi Y, Qin H, et al. Induction of oocyte-like cells from mouse embryonic stem cells by coculture with ovarian granulosa cells. Differentiation. 2007; 75:902-911. [PubMed: 17490416] 
Qing T, Shi Y, Qin H, Ye X, Wei W, Liu H, Ding M, Deng H. Induction of oocyte-like cells from mouse embryonic stem cells by co-culture with ovarian granulosa cells. Differentiation. 2007; 75(10):902-911. [PubMed: 17490416]

Resnick J, Resnick JL, Bixler LS, Cheng L, Donovan PJ. Long-term proliferation of mouse primordial germ cells in culture. Nature. 1992; 359:550-551. [PubMed: 1383830]

Richards AJ, Enders GC, Resnick JL. Differentiation of murine premigratory primordial germ cells in culture. Biol Reprod. 1999; 61:1146-1151. [PubMed: 10491656]

Rohwedel J, Sehlmeyer U, Shan J, Meister A, Wobus AM. Primordial germ cell-derived mouse embryonic germ (EG) cell in vitro resemble undifferentiated stem cells with respect to differentiation capacity and cell cycle distribution. Cell Biol Int. 1996; 20(8):579-587. [PubMed: 8938992]

Seki Y, Hayashi K, Itoh K, Mizugaki M, Saitou M, Matsui Y. Extensive and orderly reprogramming of genome-wide chromatin modifications associated with specification and early development of germ cells in mice. Dev Biol. 2005; 278:440-458. [PubMed: 15680362]

Shamblott MJ, Axelman J, Wang S, et al. Derivation of pluripotent stem cells from cultured human primordial germ cells. PNAS. 1998; 95:13726-13731. [PubMed: 9811868]

Shovlin TC, Durcova-Hills G, Surani A, McLaren A. Heterogeneity in imprinted methylation patterns of pluripotent embryonic germ cells derived from pre-migratory mouse germ cells. Dev Biol. 2008; 313(2):674-681. [PubMed: 18062950]

Smith AG. Embryo-derived stem cells: of mice and men. Ann Rev Cell Dev Biol. 2001; 17:435-462. [PubMed: 11687496]

Stewart CL, Gadi I, Bhatt H. Stem cells from primordial germ cells can reenter the germ line. Dev Biol. 1994; 161(2):626-628. [PubMed: 8314005]

Surani MA, Hayashi K, Hajkova P. Genetic and epigenetic regulators of pluripotency. Cell. 2007; 128:747-462. [PubMed: 17320511]

Tada M, Tada T, Lefebvre L, Barton SC, Surani MA. Embryonic germ cells induce epigenetic reprogramming of somatic nucleus in hybrids cells. EMBO J. 1997; 16:6510-6520. [PubMed: 9351832]

Tada T, Tada M, Hilton K, Barton SC, Sado T, Takagi N, Surani MA. Epigenotype switching of imprintable loci in embryonic germ cells. Dev Genes Evol. 1998; 207(8):551-561. [PubMed: 9510550]

Tada T, Takahama Y, Abe K, Nakatsuji N, Tada T. Nuclear reprogramming of somatic cells by in vitro hybridization with ES cells. Curr Biol. 2001; 11:1553-1558. [PubMed: 11591326]

Tam PP, Zhou SX. The allocation of epiblast cells to ectodermal and germ-line lineages is influenced by the position of the cells in the gastrulating mouse embryo. Dev Biol. 1996; 178:124-132. [PubMed: 8812114]

Tesar PJ, Chenoweth JG, Brook FA, Davies TJ, Evans EP, Mack DL, Gardner RL, Mckay RD. New cell lines from mouse epiblast share defining features with human embryonic stem cells. Nature. 2007; 448(7150):196-199. [PubMed: 17597760]

Thomson JA, Itskovitz-Eldor J, Shapiro SS, et al. Embryonic stem cell lines derived from human blastocysts. Science. 1998; 282:1145-1147. [PubMed: 9804556]

Toyooka Y, Tsunekawa N, Akasu R, Noce T. Embryonic stem cells can form germ cells in vitro. PNAS. 2003; 100(20):11457-11462. [PubMed: 14504407]

Ueno H, Turnbull BB, Weissman IL. Two-step oligoclonal development of male germ cells. PNAS. 2009; 106:175-180. [PubMed: 19098099]

Ward CM, Barrow KM, Stern PL. Significant variations in differentiation properties between independent mouse ES cell lines cultured under defined conditions. Exp Cell Res. 2004; 293(2): 229-238. [PubMed: 14729460]

Wei W, Qing T, Ye X, Liu X, Zang D, Yang D, Deng H. Primordial germ cell specification from embryonic stem cells. PLOS One. 2008; 3(12):4013-4024.

West JA, Park I, Daley GQ, Geijsen N. In vitro generation of germ cells from murine embryonic stem cells. Nat protoc. 2006; 1(4):2026-2035. [PubMed: 17487192] 
Ying Y, Qi X, Zhao GQ. Induction of primordial germ cells from murine epiblasts by synergistic action of BMP4 and BMP8B signaling pathways. PNAS. 2001; 98(14):7858-7862. [PubMed: 11427739]

Yoshimizu T, Obinata M, Matsui Y. Stage-specific tissue and cell interactions play key roles in mouse germ cell specification. Development. 2001; 128(4):481-490. [PubMed: 11171332] 

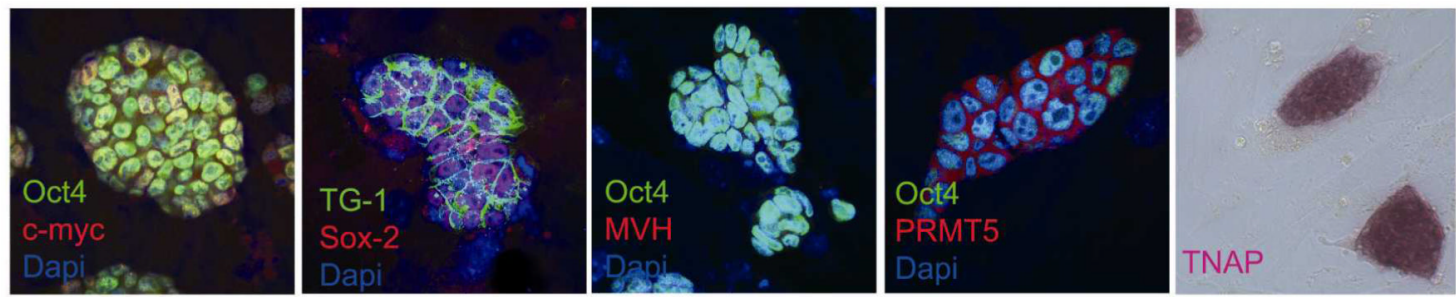

Figure 1. Characterisation of EG cell lines

Representative immunofluorescence analysis of EG cell lines grown on a feeder layer. Clear expression of EG surface marker SSEA-1, nuclear transcription factors Oct4, Sox-2 as well as c-myc and Prmt5 proteins were observed. Also we observed all colonies positives for TNAP. By contrast all colonies were negative for Mvh. 
EG cells cultivated on feeder layer

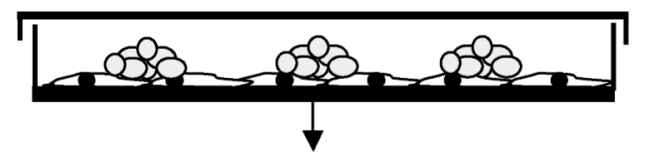

Cultivation of EG cells in hanging drops (800 cells/drop)

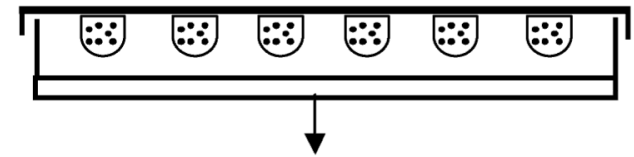

Formation of embryoid bodies for 3 days

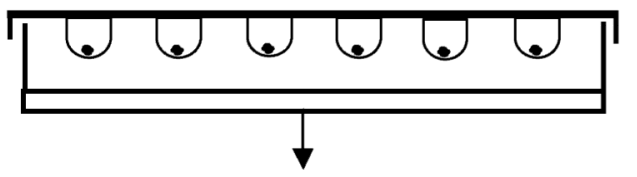

Cultivation of EB in suspension for 6 days

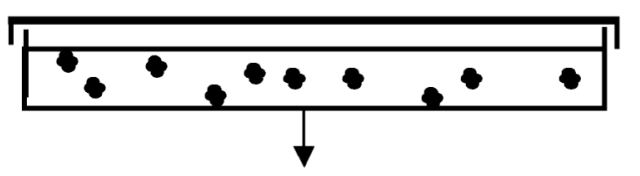

Collection of EBs from day 3-9 of differentiation

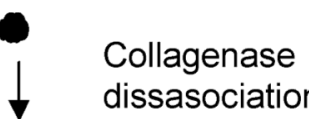

dissasociation

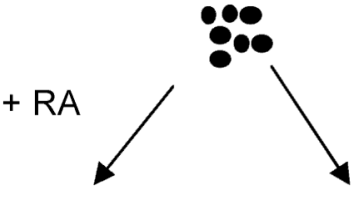

Long term cultures

coculturing with $\mathrm{CHO}$ cells

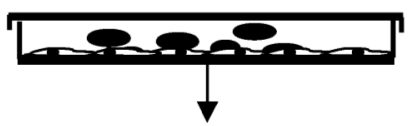

PGCs enter in meiosis after 5,10 and 12 days in culture

PGC proliferation after 5 days in culture

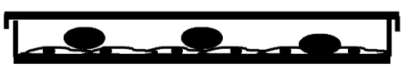

Figure 2A. Schematic illustrating the in vitro differentiation of EG cells 

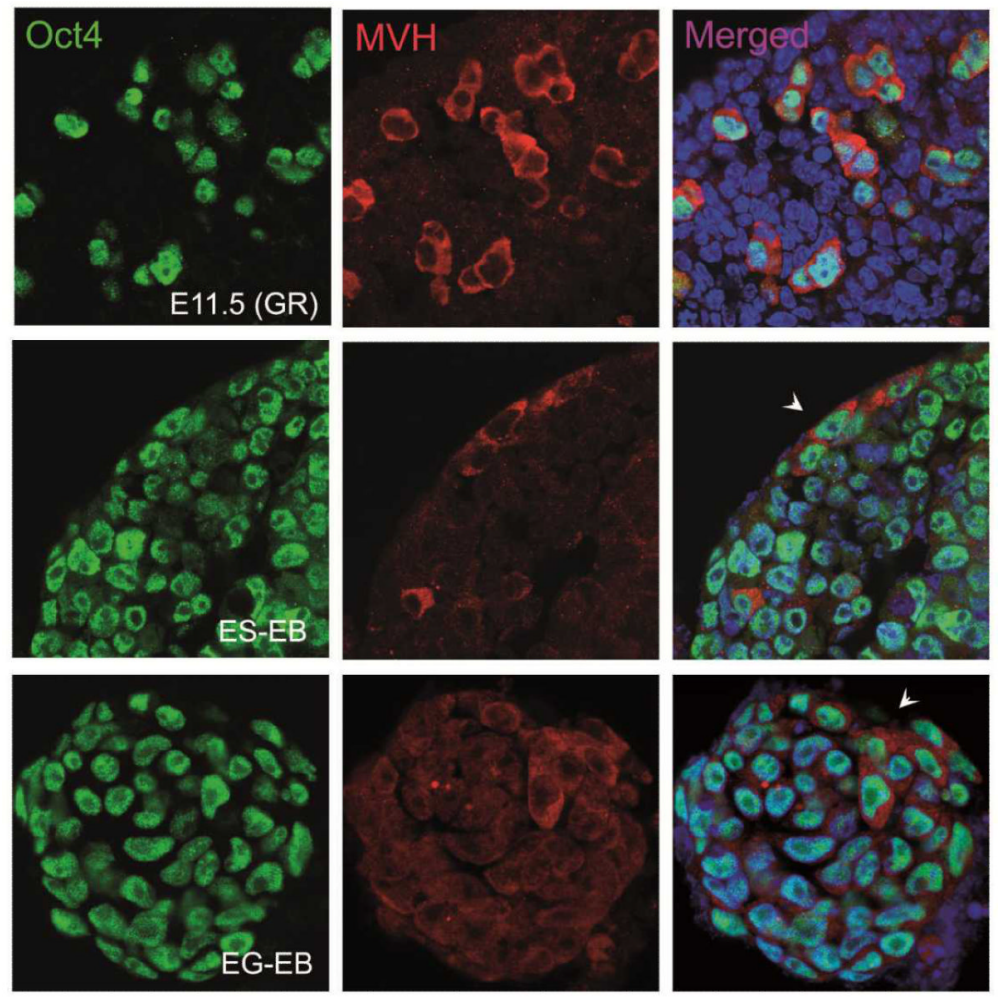

Figure 2B. Identification of PGCs in 5 days old bodies EBs derivated from ES and EG cells were cryosectioned and stained for Oct4 (green) as a pluripotency marker and Mvh (red) to detect a specific germ cell marker. We used genital ridges (GR) from $11.5 \mathrm{dpc}$ as a positive control. Arrowheads indicate some PGCs positives for both markers in EBs generated from EG and ES cells. 


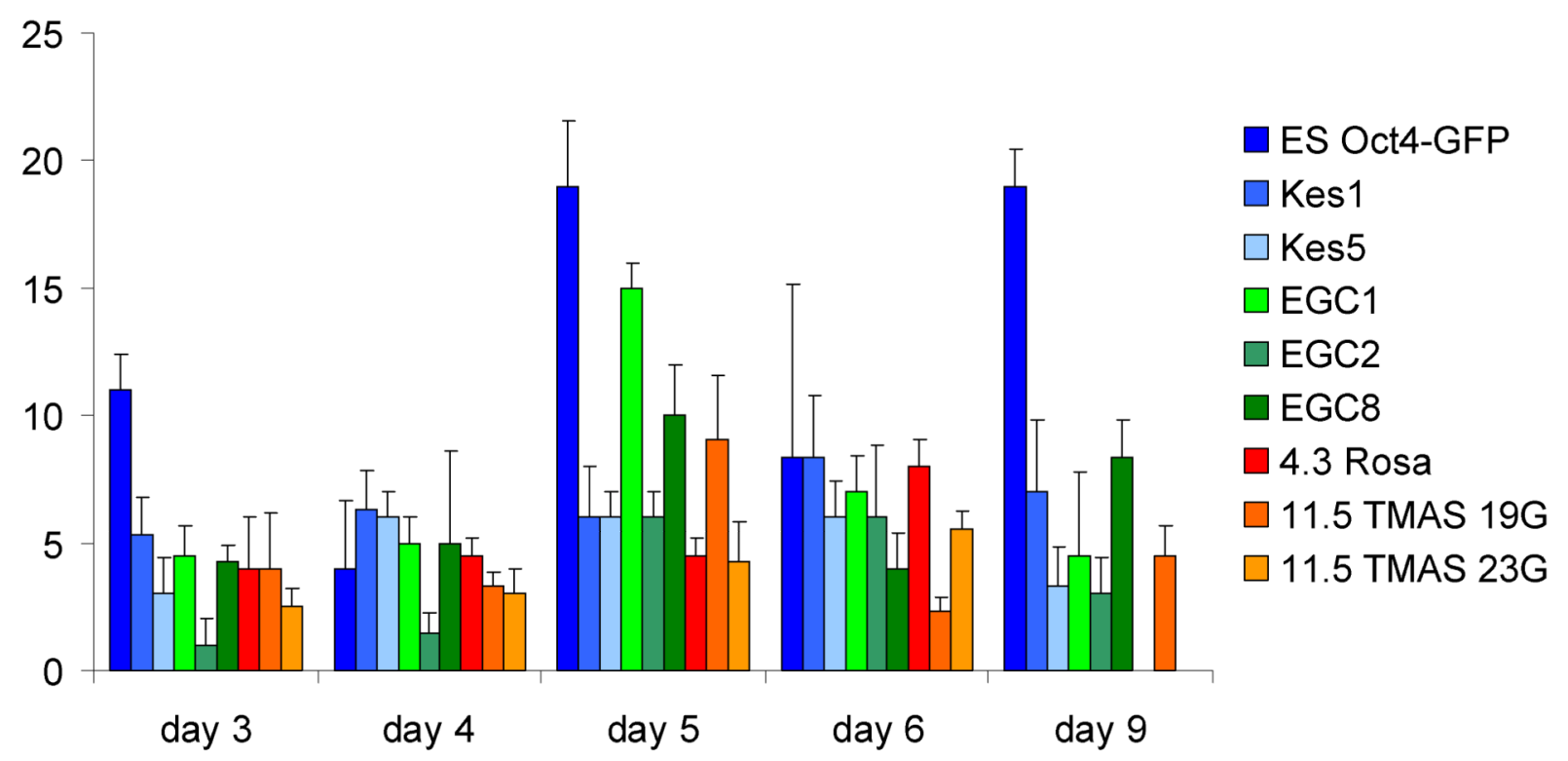

Figure 3A. Development of PGCs at several time points by differentiating EBs made from early and late EG cell lines

Bars represent the number of Mvh positive cells per EB. We used several ES, 8.5-11.5 EG cells. 

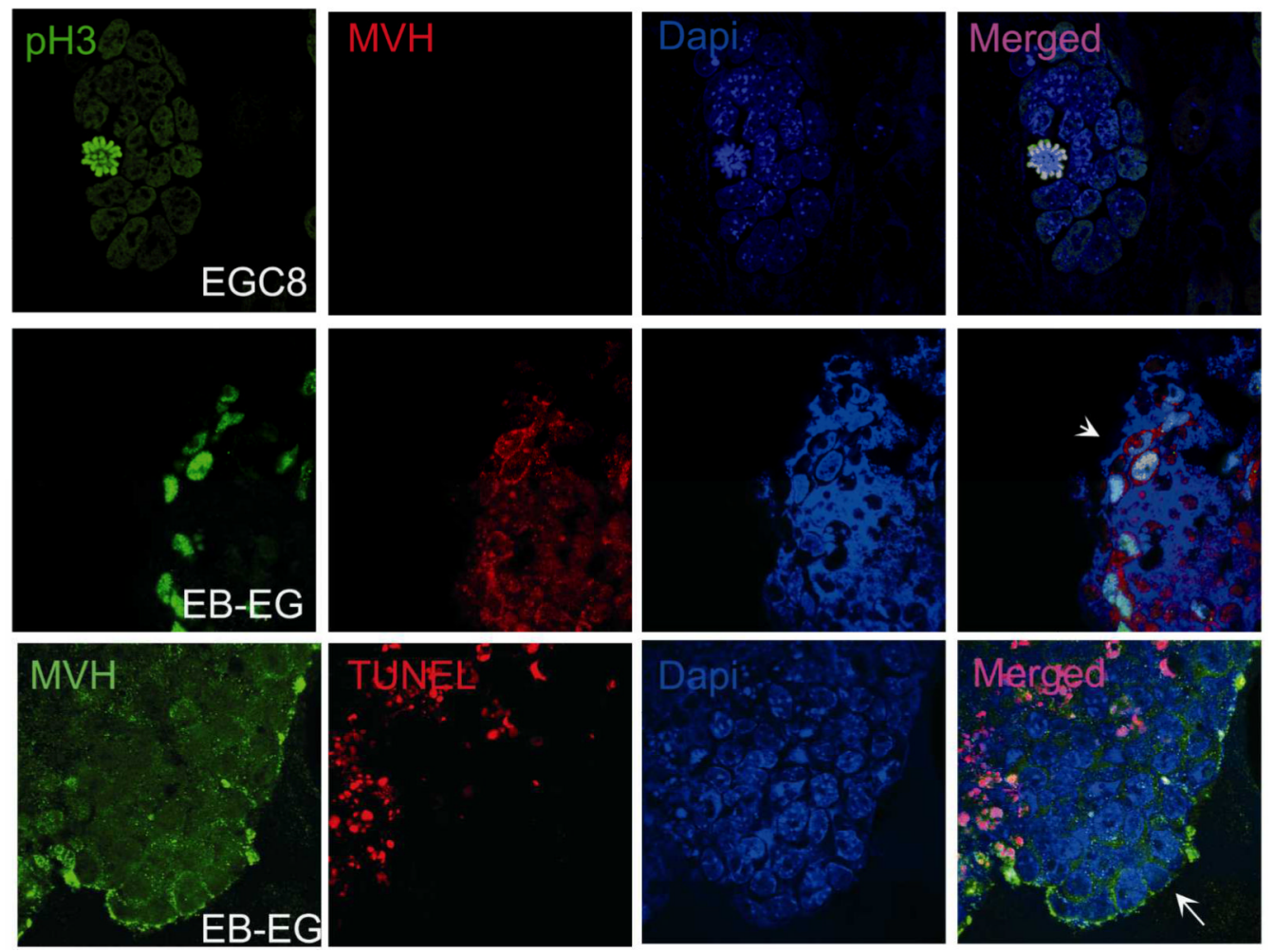

Figure 3B. Proliferation and apoptosis in newly formed PGCs from EG cells To detect proliferation in EBs derivated from EG cells were cryosectioned and stained with phosphorilated Histone 3 (PHH3) (green) as a mitotic marker and Mvh (red) to detect a specific germ cell marker. We used EG cell line as a positive control. Then we used TUNEL reaction to detect apoptosis (red) in combination with Mvh (green). Arrowhead shows proliferating PGCs and the arrow indicates non apoptotic cells during the in vitro PGC formation. 

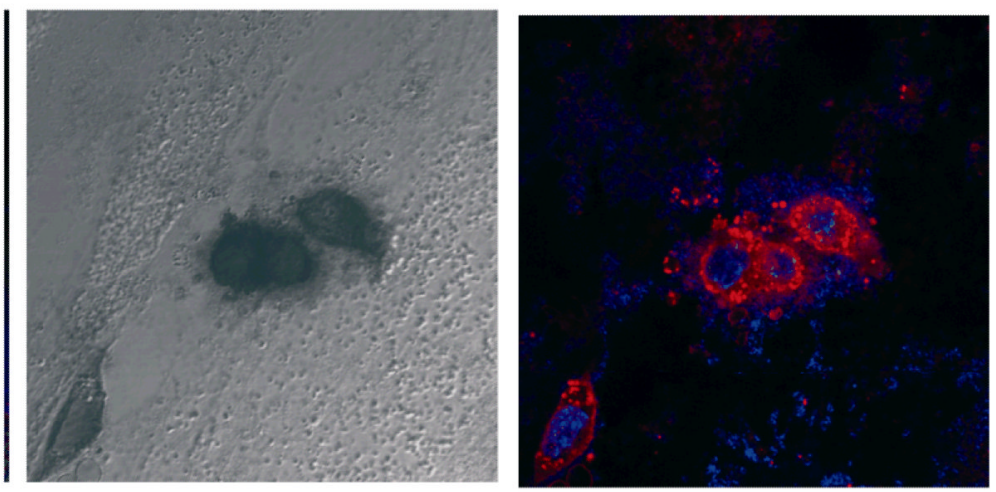

Figure 4. Generation of PGCs after culturing 5 days old bodies with RA treatment for 5 days We cultured EBs formed from EG cells with RA during 5 days. Then, we combined AP staining with immunofluoresce technique, using Mvh (red) marker to demonstrate both typical markers of PGCs. 

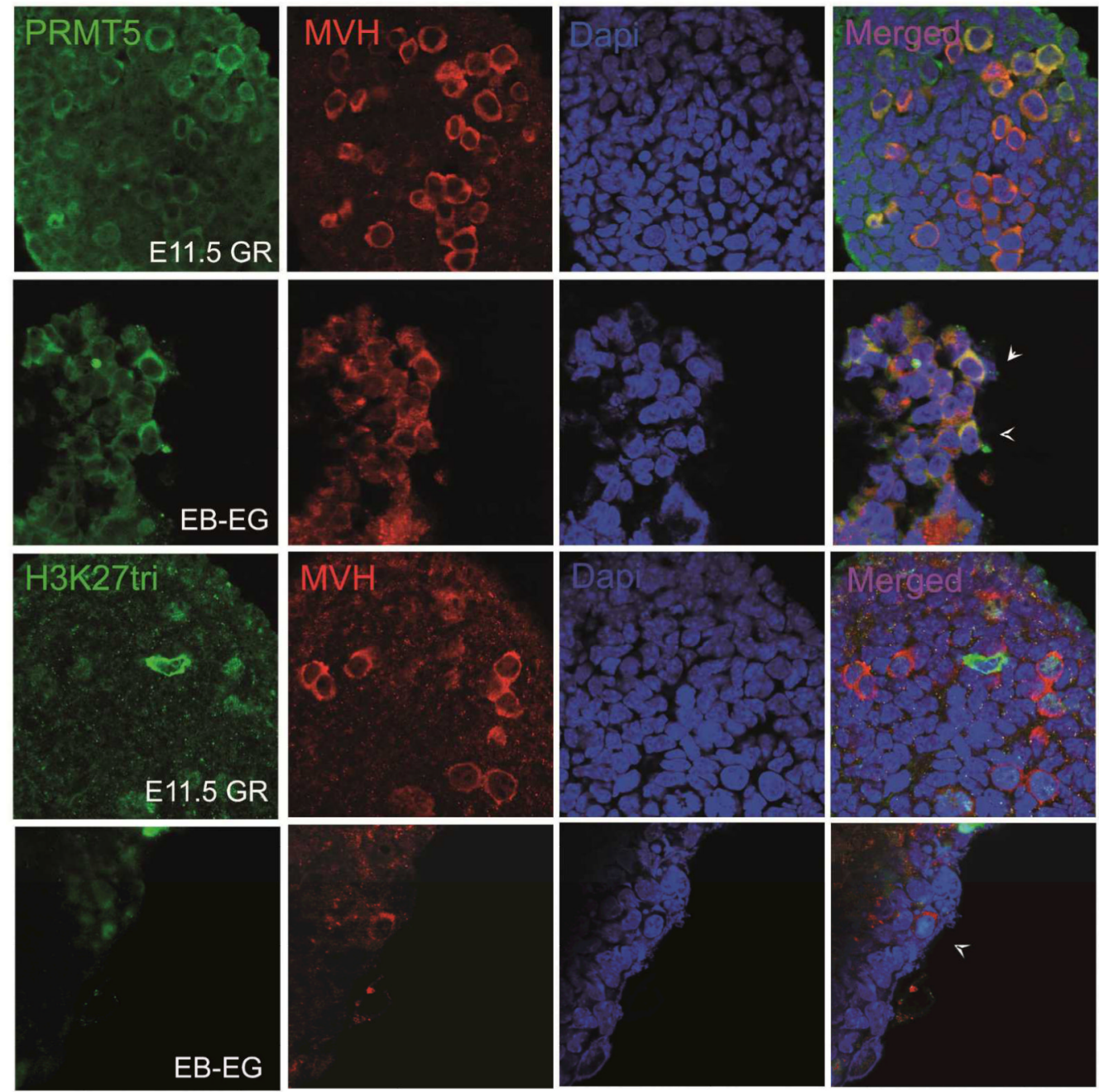

Figure 5. Epigenetic status of in vitro PGCs

Expression of several histone modification markers of late PGCs, as Prmt5 and H3K27-tri (green) in combination with another specific germ cell marker, Mvh (red). We used genital ridges (GR) from $11.5 \mathrm{dpc}$ as a positive control. Arrowheads indicate the expression of both histone modifications in these newly formed PGCs are similar to in vivo 11.5 PGCs. 


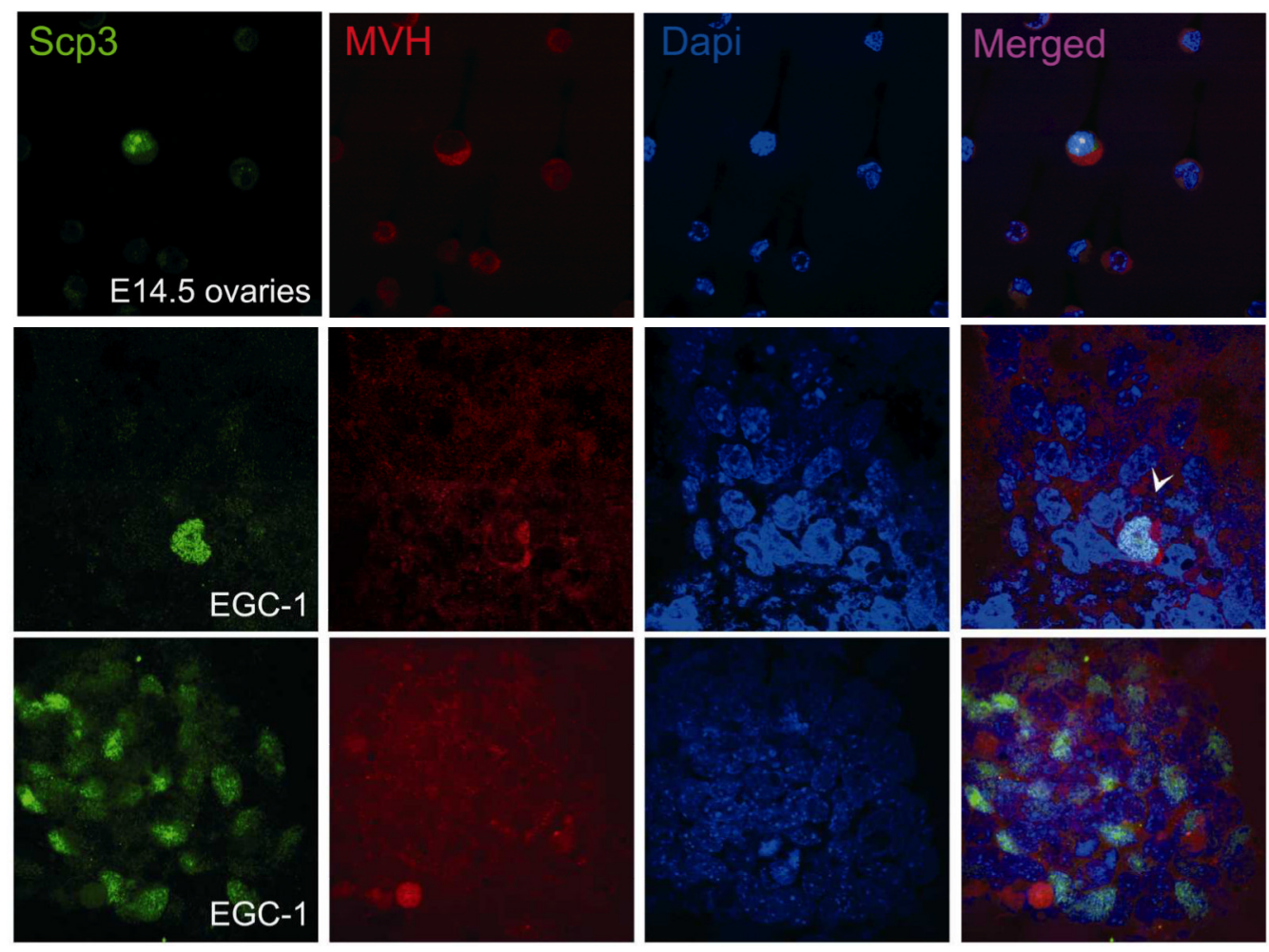

Figure 6. Expression of a meiotic marker in long-term cultures of EBs

Immunofluorescence of 5 days old bodies derived from EG and ES cells co-cultured with CHO cells for 5 days. We observed positive cells for Scp3 (green) and Mvh (red) markers indicating enter into meiosis (arrowhead). We used single cell suspension of fetal ovaries from $14.5 \mathrm{dpc}$ as a Scp3 and Mvh controls. 
Table 1

Pluripotent cell lines used in this study

\begin{tabular}{cccc}
\hline $\begin{array}{c}\text { Name of the } \\
\text { cell line }\end{array}$ & $\begin{array}{c}\text { Cell } \\
\text { type }\end{array}$ & Mouse strain & Sex \\
\hline ES-Oct4GFP & ESC & C57/B6 $\times$ C57/B6 & M \\
Kes-1 & ESC & $129 \times 129$ & M \\
Kes-5 & ESC & $129 \times 129$ & F \\
EGC-1 & eEGC & MF1 $\times$ Rosa & M \\
EGC-2 & eEGC & MF1 $\times$ Rosa & M \\
EGC-8 & eEGC & MF1 $\times$ Rosa & F \\
4.3 Rosa & 1EGC & MF1 $\times$ Rosa & M \\
TMAS 23G & 1EGC & $129 \times 129 /$ Rosa & M \\
TMAS 19G & 1EGC & $129 \times 129 /$ Rosa & F \\
\hline
\end{tabular}

Differentiation. Author manuscript; available in PMC 2013 December 03. 
Table 2

\section{Characterisation of pluripotent stem cells}

\begin{tabular}{ccccccccc}
\hline \multirow{2}{*}{ EB formation $\left(^{*}\right)$} & \multicolumn{7}{c}{ Characterization of pluripotent stem cell lines } \\
& Oct4 & Sox2 & c-myc & SSEA-1 & PRMT5 & MVH & TNAP \\
\hline+++ & + & + & + & + & + & - & + \\
+++ & + & + & + & + & + & - & + \\
++ & + & + & + & + & + & - & + \\
+++ & + & + & + & + & + & - & + \\
++ & + & + & + & + & + & - & + \\
+++ & + & + & + & + & + & - & + \\
++ & + & + & + & + & + & - & + \\
++ & + & + & + & + & + & - & + \\
+++ & + & + & + & + & + & - & + \\
\hline Variation in differentiation properties between cell lines $(+++$, excellent;,++ good $)$.
\end{tabular}

